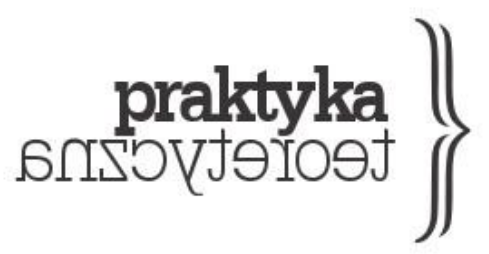

ISSN 2081-8130

DOI: $10.14746 /$ prt.2018.2.2 www.praktykateoretyczna.pl

\title{
PLASTIC CARTOGRAPHIES. MAP AND TERRITORY IN CATHERINE MALABOU AND ECOPOETICS
}

\author{
GRZEGORZ CZEMIEL
}

\begin{abstract}
This article analyses the theme of map and territory in Catherine Malabou's philosophy and in contemporary poetry. Calling into question the traditional understanding of the tension between map and territory, Malabou emphasizes that no map can entirely distance itself from territory, as in the case of the brain's development in contact with the environment. Malabou employs cartographic ideas to clarify her own concepts of "plasticity" and "brain-world cartographies" that account for how the environment shapes us, at the same time indicating how we may partake in this process. Viewing selected works by Elizabeth Bishop and Nigel Forde in this perspective, which is demonstrated to dovetail with ecopoetics, this article explores how poetry can offer tools necessary for developing better ecologies of the mind. This is particularly urgent given the ongoing ecological crises as well as ethical challenges entailed by the advent of the Anthropocene and the scaling up of global capitalism.
\end{abstract}

Keywords: plasticity; cartography; mapping; poetry; ecopoetics. 


\section{Introduction: Crusoe's brain}

After Robinson Crusoe returned to England - as Elizabeth Bishop imagines in her poetic postscript to Daniel Defoe's 1719 novel - he became disillusioned and disgruntled over the loss of the desert island that had been his home for so long. Upon reading about a new volcanic island being born and named, he disaffectedly remarks that "my poor old island's still / un-rediscovered, un-renamable" (Bishop 2011, 182). First published in The New Yorker in 1971, "Crusoe in England" was later included in her last collection Geography III (1976), whose title confirms the geographical dimension of her work, later elaborated upon extensively by numerous scholars. Bishop's preoccupation with topographical detail and cartography intersects with questions of identity and subjectivity. The ageing Crusoe, who looks back upon his life, seems to be captivated by the notion of islands, which haunt him in his dreams, manifesting in nightmarish visions of "infinities / of islands, islands spawning islands" - an archipelago he would be doomed to study eternally, "registering their flora, / their fauna, their geography" (185). Ultimately, he concludes, these islands have come to permeate his very self:

My blood was full of them; my brain

bred islands. But that archipelago

has petered out. I'm old.

The sense of his island falling into oblivion, despite his lifelong efforts to chart it, is linked to the tension that looms large over Bishop's oeuvre, as announced in the poem "The Map," which opens her first collection North \& South (1946). It is the tension between the map and the territory. This double figure has proven ripe in meaning, explored throughout the twentieth century in all of the humanities - popping up in literary studies, philosophy, and human geography. Bishop's famous declaration that " $[\mathrm{m}]$ ore delicate than the historians' are the map-makers' colors" (5) remains a touchstone for many thinkers who have taken up the theme of mapmaking, identifying it is a fundamental trope in both epistemology and the arts, including poetry.

The retrospective character of "Crusoe in England" does not only embrace the conclusion that maps are artificial constructs, and therefore bound to have one foot stuck 
in fiction, but foregrounds their temporal dimension as well. The lyrical subject feels that his "un-rediscovered" island is sinking into oblivion, falling off the edge of the charted world. "Crusoe," Katie Ford observes, "has the desire for his island to be on the map of the other not just any map, but a map continuously corrected" (2007). In old age he suffers from a profound sense of a loss of the world, which has "petered out," leaving him emptied, bored, and brain-dumb. In this sense, as Ford argues further, "[h]e wants someone to chart not only geographical islands, but also the islands of the mind." England does not seem to offer him much consolation and he fails to revive within himself that creative spark which allowed him to make an actual home on a remote desert island. In other words, his cartographic imagination is running dry as his map fades and withers. "The creation of poetry and the landscape of the island," Ann Marie Fallon writes, "are inextricably linked throughout the poem" (2016, 21). Crusoe's brain no longer "breeds" new geographies and the colours of his maps fade as he himself is left mourning the departure of his old self.

The problem posed by Bishop is whether there exists a form that could hold Crusoe's island in its splendid detail and simultaneously account for the distance produced by having departed from it. Throughout her work we encounter this fundamental question: Is it possible to develop a mode of mapping that would give justice to the incredible detail of the world, and yet somehow account for the changes that this world is undergoing, both in itself and as an imprint pressed upon the mind of the experiencing subject? Bishop approached this issue both from the thematic perspective - examining in her poems various topographies of imagination and positioning them on the backdrop of the larger world as well as from the formal point of view, attempting to develop the kind of poetic form that could successfully pose this problem. In problematizing this she turned towards the metaphor of cartography, trying to find out what kind of a poetic "projection" could account not only for the territory itself but also for the mapmakers' complex and shifting relationship with it.

The subject of the mind and its relationship with the environment - manifesting in a specific brain-cartography and poetically elaborated in "Crusoe in England" - could be framed in terms developed within two areas of theoretical enquiry: on the one hand, the philosophy of Catherine Malabou, and on the other - the discourse of ecopoetics, a thriving new idiom in literary criticism. These two theoretical positions in turn share an important impulse, namely the desire to probe how alternative, more sustainable modes of engagement with the natural environment could be ushered in. Since Catherine Malabou fleshes out a specifically cartographic account of brain development and advances the notion of a "brainfiction," this essay attempts to trace a connection between her philosophy and the fundamental tenet of ecopoetics: the idea that poetry's creative use of metaphor makes it capable of reconfiguring our understanding of the world by bringing to our attention 
precisely what Malabou calls "plasticity" and allowing to identify her notion of "brain fiction" with the workings of poetry. Moreover, reading and writing become, in this light, powerful tools that not only facilitate a deeper awareness of humanity's embededness in the world, but also help model relationships with others and the natural environment. Therefore, taking cue from ecopoetics, Malabou could be seen as providing a valuable theoretical underpinning for a new ecologically-inflected concept of writing - a "plastic cartography" - in which we transform ourselves by renewing the relationship with the brain-world as our basic environment.

\section{Cartography and the brain: Catherine Malabou}

In her seminal work titled What Should We Do with Our Brain? (2008) Malabou elaborates on the concept of "plasticity," developed at the intersection of philosophy and neuroscience. She traces the various historical notions of the human brain and offers her own account of how plasticity elucidates the formation of the brain throughout human life. Already at the onset, Malabou defines the "plastic art of the brain" as involving the "establishing of [neural] connections" and "modelling them" in contact with one's environment (19-20). Rejecting the cybernetic concept of the brain as a central processing unit, she embraces a networked account of the nervous system's activity, which was likened by Marc Jeannerod to a "multidimensional map" (35). This plastic map is, in her view, "precisely the form of our world," although - for that very reason - we fail to notice it and, in consequence, can remain oblivious to the power relations inscribed in it, which are thus perpetuated in social life (3839). Turning to films by Alain Resnais and Stanley Kubrick, she further reasserts that in their works "landscapes are mental states" or "cartographies" that bring to our attention "the identity of the brain and the world," or simply the unity of the "brain-world" (39). Thus, the "delocalized" brain is not just a commanding organ but rather an archipelago of "multiple interconnected functional spaces, always in movement and susceptible to self-modification" (43), while its fundamental feature is the "power to configure the world" (39).

Given the above, it becomes clear why Malabou wishes to develop the kind of philosophical language that would account for the brain's work and liberate it from those world-configurations that stifle its operation. It is this search for a discourse in which "the neuronal man" could "know how to speak of himself" that Malabou's philosophical ambition intersects with Bishop's. Both employ the metaphor of map (brain) and territory (world) to show that humanity is effectively shaped by its environment and cannot be detached from it in the way that the seemingly objective projects of scientific cartography can lead us to believe. At the same time, though, it becomes crucial to account for these formative processes and grow aware of the brain's plasticity so as to put up resistance to 
those tendencies that immobilize the brain in terms of both ethics and aesthetics. These two dimensions in fact collapse into one another. The ethical dimension, as emphasized by Malabou, would consist in "the political emancipation of the brain," which is necessary to overcome the political inertia that leads to what she has called the loss of affects, particularly loss of wonder $(2013,62)$, the kind of malady that Crusoe clearly suffers from. Bishop, in turn, was particularly interested in such concentrated, "wondrous" use of detail that could "entrance" readers, rewiring their mental mapping systems so that they can be sent - to quote from her famous "Darwin letter" - "sliding giddily off into the unknown" (after Pickard 2004, 281), i.e. into what Malabou has called "a new world of questioning” (2008, $54)$.

The unknown that Bishop writes about can be fruitfully juxtaposed with Malabou's concept of "neuro-literature" (2016). Elaborating on the thought of Michel Foucault and Maurice Blanchot, she posits that neurobiology is actually the "absolute outside of literature that gives the outside in literature its effective meaning" (79). Thus, the brain-world that emerges from a given literary work as its mental geography - as in the case of Crusoe's endless chains of islands - has to be understood then as a brain topography mediated through language. Blanchot's death-like, neutral "space of literature" is transformed in her account into "the very expression of the traumatized psyche and, in any case, of the brain's fundamental fragility" (81). In this light, as she argues, fiction is what the brain creates in order to experience itself, because it can have no real access to the neuronal make-up that is of pre-verbal nature (81). No self-reflection of the brain is possible without invention, i.e. by developing what Slavoj Žižek called "a fiction observing its own fiction" (after Malabou 2016, 87). Therefore, what she attempts is not a reductionist view of literature as a form of expression entirely determined by unconscious physical and chemical processes inside the brain. She rather perceives it as a supreme fiction that brings to our attention the existence of the brain, which is otherwise entirely external and inaccessible. Indeed, if we assume that "neural experience develops itself as literature" (81), then literature acquires a fundamental role in identifying the plastic histories of the brain and in providing it with the experimental field in which mental cartographies can be first acknowledged, then interpreted, and finally shaped.

These observations can be supplemented with the perspective offered by ecopoetics - a relatively young approach developed within literary studies, which sets as its aim the examination of literature's relationship with the environment. As Tom Bristow (2015) argues, ecopoetics is fundamentally engaged with geography understood in the broadest (and quite literal) sense as "earth-writing," i.e. a recording of the ties between the human and the non-human. Because poetry is a mode in which "we are abnormally sensitive creatures" (3), it foregrounds the fragility and plasticity that Malabou is emphasizing, 
especially in relation to humanity's embeddedness in its environment. Further, dovetailing with Malabou's call to resist the political by reviving ecological imagination, ecopoetics urges "to reflect on how we imagine spaces and formations beyond the purview of the sense horizon, at pace enough to notice and acknowledge discrete entities and the emergence of our earth others" (9). This task becomes all the more pertinent in the face of ongoing ecological crises and in the context of the Anthropocene, a geological era in which humanity has become the major force changing the face of earth, and thus one that calls for more responsible ways of home-making on a planet that cannot sustain us given the prevalent anthropocentric politics. To achieve that goal, ecopoetics must work closely with new ontologies, particularly materialist ones, which help reimagine the world as an ecosystem in which humanity is basically dependent on the non-human. Due to poetry's potential to forge new metaphors and subjectivities through extensive and processual manipulation of the lyrical "I," it offers a linguistic laboratory where such novel discourses can be developed, i.e. ones that, firstly, "reaffirm the world in its complexity," and secondly, "account for our accounting of the human's place within this world" (12). To achieve this goal, however, ecopoetics cannot resort to idyllic, conservatively pastoral views of nature, but must seek to foster a new consciousness that would utilize the constructive component of plasticity in order to devise lifestyles and ethics of care that promote sustainable alternatives to the exploitative capitalism of the neoliberal regime.

A reading of Malabou's work alongside ecopoetic criticism allows us to locate within poetry the model of cartographic operations she identifies as being at work in the brain. Crusoe's situation is paradigmatic in this respect and facilitates developing an epistemology of the kind of mapping that is termed here "plastic cartography." In this account, the map is understood as a process in which subjectivity is born and transformed through the metaphorization of territory as brain-territory. In this sense, the metaphor does not produce merely an image or concept, but actively shapes the brain-world by landscaping it. Crusoe's brain, in this sense, is a brain-island created by his old dwelling place imprinting itself in his mind and changing in time. Malabou's understanding of plasticity as both positive and negative dovetails with the argument made by ecopoetics, namely that developing better metaphors and refining our mental maps of connections with humans and non-humans can help achieve a transformation of subjectivity akin to processes identified in poetry as the creation of the lyrical persona. In this case though, the aesthetic aim of creating a believable literary character is fused with the ethical one of finding out how one can actually change in order to accommodate a broader, more hospitable concept of humanity enmeshed with the entirety of the natural environment, which it is a part of. 


\section{Lyrical and subjective plasticity}

Ecopoetics points out that in order to adjust to the realities of the Anthropocene new modes of engagement with the world are necessary, which must entail a shift in how the human subject is construed. Instead of attending to the paradigm of human dominance, which is clearly exemplified in imperialist cartographies that posit the natural world as a repository of resources and a system of nodes for capitalist expansion, ecopoetry advocates the rise of subjectivities that would thoroughly acknowledge their rootedness in earthly materiality. In line with recent developments in more-than-human ontologies, the human subject needs to conceive of itself as a site where both human and non-human forces criss-cross and equally contribute to the rise of our subjecthood. Bristow, for example, proposes to speak of "selfhood as Worldliness" - a more capacious view of humanity that shares its environment with non-human others and relinquishes the "conquering gaze" in order to "rethink our personhood within a larger domain of life" $(2015,6)$. In this light, a new, more ecological account of the oikos (home) becomes the foundation for developing a deeper sense of care for a world in which humans no longer occupy any privileged position but are rather one of many agents operating in a vast network of interrelations, which extends far beyond the horizons of instrumental and reductive reason. We cannot think of ourselves any longer as "separate or authoritative" but ought to embrace a revised view of humanity woven into a "continuum" shared with others (16). For that purpose, it becomes necessary to seek "particular strategies for stepping outside of the self" in an attempt to overcome the limitations of narrowly conceived and short-sighted human domination (16). Bristow openly claims that this can be achieved in poetry, where a "lyrical meta-consciousness" could, at least to some extent, allow "the environment to speak itself" by opening up the lyrical subject to the flows of a larger reality to which we can lay no ultimate claim of possession or control.

Malabou helps to theorize this by introducing the concept of a brain plasticity that facilitates subjective metamorphoses - which she terms "transsubjectivization," referring to the philosophy of G.W.F. Hegel. In an interview with Noëlle Vahanian, she emphasizes that this process does not necessarily mean we need to become entirely different or appropriate difference from the other, but rather involves tracing a trajectory within oneself in an effort to "open a space within yourself between two forms of yourself," enabling a "journey within oneself" that results in transformation $(2008,5)$. Such a spacing of personality could “produce a new self" precisely by embracing plasticity, which releases the potential to change, both for the better (in efforts to transsubjectivize in the face of the Anthropocene, developing a new consciousness) and for the worse (as she underlines in her numerous elaborations on trauma, old age, Alzheimer's disease etc., cf. Malabou 2012). The metaphors 
she employs to discuss this - notably, "spacing" and "journeying" - make it possible to align these conclusions with the cartographic metaphor discussed above, which casts this problem in terms of developing novel maps of the self - i.e. poetic brain-fictions that foreground the cartographic unity of brain and environment - and acknowledging a wider reality to which we continuously try to attune. The spacing of selves made possible within poetry shall be revisited later on the occasion of discussing poetry by Nigel Forde, who demonstrates how poetry can achieve this goal by working through memories and past selves, not exactly shattering subjective unity but expanding the capacity of the self to contain more than just oneself, opening up to the world.

This goal is also expounded by Félix Guattari in The Three Ecologies, where he overtly voices the necessity for "continual reinvention" of both "individual and collective subjective assamblages" in cartographic terms:

\begin{abstract}
As in painting or literature, the concrete performance of these cartographies requires that they evolve and innovate, that they open up new futures, without their authors having prior recourse to assured theoretical principles or to the authority of a group, a school or an academy $(2000,40)$.
\end{abstract}

To employ the theoretical language he developed together with Gilles Deleuze, one could say that nowadays it becomes paramount to seek "lines of flight" that would guide us away from pre-established political forms perpetuating the "nightmarish" status quo that throws a "stifling cloak of silence over the emancipatory struggles of women, and of the new proletariat: the unemployed, the 'marginalized', immigrants" (44). In order to chart "escape routes" and novel "existential indices," it is essential to work on "mapping out the cartographic reference points of the three ecologies," namely: social ecology, mental ecology, and environmental ecology (41). These three demand reintegration through more holistic mapmaking strategies, which would counteract the degradation of human solidarity in the face of the migration crisis and the environmental crisis, as well as the crisis of political and ecological imagination.

Guattari further develops these ideas in Schizoanalytic Cartographies, where he endeavours to formulate speculative modelling systems that would exceed traditionally understood subjectivities of individual monads. Instead of relying on ready-made formulas that imprint themselves on the brain (e.g. the "flexibility" analysed by Malabou), "schizoanalytic meta-modelling will choose to map compositions of the unconscious, contingent topographies, evolving with social formations, technologies, arts, sciences, etc." 
$(2013,22)$. Overcoming rigid mappings that trap contemporary subjectivities in the "flexible" regime of illusionary freedom, new cartographies of the self must be produced actively because they cannot arise spontaneously. The ultimate goal would be to reclaim the "power of existential production" so as to facilitate imagining new existential territories as a more inclusive and democratic oikos that welcomes and makes room for not only all humans but also our non-human earthly cohabitants. In the present perspective, Guattari's schizoanalytic mapmaking constitutes a full-blown answer to Malabou's question about what we should be doing with our brains.

Taking the cartographic metaphor further, it becomes necessary to question whether such schizoanalytic remappings can aspire to produce any total vision. Guattari seems to be wary of any such prospects. Does it mean that mapping has to limit itself to the immediate habitat? Geoff King tackles this question in Mapping Reality (1996), arguing that this is not a matter of choosing between the two perspectives - the imperial, all-encompassing bird'seye view of technological and political dominance on the one hand, and the parochial, idyllic, local and place-bound view of one's closest milieu on the other. Invoking Fredric Jameson's concept of "cognitive mapping," he concludes that neither seem to work as long as they remain "a simple act of mimetic representation" (15). What is at stake here is not to choose between the global and the local, but rather to acknowledge both the inherent situatedness of all mappings, and the necessity to think of the whole in relation to which one is positioned, although this totality cannot be simply laid down in reductive terms of national boundaries or routes along which capital flows in the global financial system. Thus, it is crucial to "blur the distinction between map and territory" in order to "destabilize this relationship, to acknowledge the socially constructed character of the mappings within which our lives are oriented"; this also entails creating the possibility to change, all the while carrying in mind that "we should not underestimate the power with which particular mappings can continue to impose themselves even against our will" (16-17). One mode in which such a "destabilizing" can be achieved is poetry, where all of the above crucial tensions are foregrounded. Springing from its rootedness in the particularities of the place, poetry can show us how the metamodelling of the mental map takes place. By engaging with metaphor, however, poetry can suggest or imply larger totalities that extend beyond the purview of the conceptual frames imprinted in us by the dominant aesthetic regime. Finally, through its ability to subvert the lyrical subject, poetry can consciously sculpt blueprints for future selfhoods. 


\section{The sculpting of the synaptic self and the lyrical brain of history}

It is in Catherine Malabou's concept of the self that the cartographic metaphor is reworked in a way that transforms the traditional understanding of the figure of map and territory. "The 'self," she writes, "is a synthesis of all the plastic processes at work in the brain; this permits us to hold together and unify the cartography of networks" (2008, 58; emphasis added). The first map produced by the brain is one related to the process of the brain representing itself. What emerges in this process of self-mapping is the "blurring of the borders between brain and psyche" (60). As these processes intensify and extend onto the realm of objects, further layers are added to these mappings. Interestingly, as Malabou progresses to elucidate this, taking cue from Antonio Damasio, she goes on to argue that these proto-cartographies reveal the operation of "something like a poetic activity" (60). This "cerebral poetry" would be responsible for the transition from the neuronal level to the mental, thus providing a bridge linking the (mental) map and the (neuronal) territory. In a turn of phrase that brings to mind claims made in biosemiotics, Malabou concludes that in the very networked character of interconnected neurons there is already something at work that makes them predisposed to expression of meaning.

This, however, is possible only thanks to the brain's plasticity, which can have as already noted - both positive and negative effects. After all, as Malabou often recalls, "plastic" can also indicate a "plastic explosive," which testifies to the potentially destructive, change-inducing character of plasticity. In mild doses, however, these explosive occurrences act like "creative bursts that progressively transform nature into freedom" (74). Thus, by offering a possibility of introducing discontinuities and gaps in the smoothed-out surface of the brain, shaping and moulding it, neuroplasticity can be seen as an agent of change or reform. It is precisely this function that has been often attributed to poetry, which uses language in order to subvert our perceptual habits by introducing obstacles, providing challenges to sense-making mechanisms, thus inclining us to look at the world from a fresh perspective and reconsider the hierarchies that we have come to follow blindly. Such modes of "defamiliarization" (term coined by Victor Shklovsky), "retardation," "estrangement" and "weirding" (Graham Harman's concept) have been the staple of poetic language since the beginning of literature. What these effects contribute to is not a purely mimetic representation of the reality "as it is" but rather a way of counteracting the closure of the gap between world and language. This feature of poetry clearly dovetails with Jameson's predilection for non-representative modes of mapping, and with Malabou's contention that 
the one thing we should definitely do with our brains is "not to replicate the caricature of the world," by which she means the current, unsustainable and destructive form of global capitalism (78). In order to do so, she concludes, new mental maps are necessary because they would facilitate establishing a novel relationship between ourselves and our brains: one that invites a world to come, rather than the one that wishes to perpetuate itself in a cycle of self-destructive repetition compulsion (82).

The "brain-world to come" that needs to be ushered in with great responsibility and care is of course related to redefining what she calls "the history of mentality": instead of considering it from a purely specieist, egotistic perspective of humanity-as-crown-of-being, she advocates acknowledging that our mentality crucially includes "the materiality of inorganic nature, the soil, the rocks, the mountains, the rivers, the earth" $(2017,51)$. In this she attempts to embrace the "geological becoming of the human" - a gesture she shares with thinkers like Gilles Deleuze and Félix Guattari, as well as with Rosi Braidotti, Karen Barad, and Donna Haraway (cf. Reinertsen 2016). Despite differences in position among the above, the general and crucial tendency is that they all share one fundamental, ecological premise, namely that we should not think of the brain as existing in the environment but rather consider the brain as an environment (52). One cannot underestimate the significance of this philosophical gesture: annulling the partitioning of the environment along the dividing lines of nature-culture, human-nonhuman, subject-object etc. involves a radical democratization of ontology (dethroning humanity and acknowledging its rootedness in the entirety of the ecosystem it is a part of) as well as a reconsideration of agency and causality. These issues are being widely discussed in the humanities today as a sense of urgency sets in due to the impending catastrophes caused by manmade climate change and rampant growth of unchecked capital operations.

One particularly valuable ally in this, as it turns out, is literature. As Yves Citton observes in an essay that combines ecological considerations with questions of literature's possible role in the face of the Anthropocene, the "Earthbound" - as Bruno Latour calls those who embrace the fact that "the individual is its environment" (Citton 2016, 320; emphasis preserved) - should primarily focus on reading and writing literature. She argues that this field is particularly predisposed to aid us in learning to "compose" the world anew by weaving our lives and values together in accordance with novel coordinates and projections. Refusing to be mere land-surveyors or traditional cartographers, the Earthbound need literature as an "agent of worlding" that has the poetic capacity "to express our perspectives of becoming" (321). This is not just about writing but also reading, or "literary forms of attention" as Citton puts it, since it is vital to "delay projecting our preexisting categorization upon the environment, in order to become more attentive to our milieu's weaker signals" (321). Just like in the ecopoetic framework, literature - our perhaps 
even more broadly speaking: "literary attention" - is the medium that binds us to the Earth, making us "Earth-bound." Invoking Latour's concept of "loops," Citton points out that the key shift would consist in abandoning the perspective of domination, which fixes places from a detached perspective unbound from Earth, and embracing a mode of thinking that favours "loops" starting from the landscape and coming back to us. These new meridians would offer a different grid that could form the starting point for novel mappings fit for the Anthropocene. Citton puts forward that the literary answer to this is to trace how these "'entangled and retroactive loops' that weave our common lives, must originate 'from the landscape back to us"' (322). Loops of this kind are primarily meant to foreground how our actions have consequences on the global scale, e.g. as regarding the pollution of the oceans that begins with throwing away a plastic cup, or manmade global climate change spawning hurricanes that begins with taking a petrol-powered car to work.

Loops offer different grids for imagining earth and mapmaking, effectively overcoming what Tim Ingold has called the "cartographic illusion" (2000). Using an anthropological perspective, he demonstrates how "mapmaking" (in his argumentation identical to detached cartography) may create "the appearance that the structure of the map springs directly from the structure of the world, as though the mapmaker served merely to mediate a transcription from one to the other" (234). This illusion is dangerous because it "brackets out" two important processes: "wayfinding" (movement of people) and "mapping" (inscribing of this movement in gesture or writing), ultimately presenting a world that appears to us "like a theatrical stage from which all the actors have mysteriously disappeared [...] devoid of life" (234). Ingold contrasts this with mappings practiced by North American Indians or the Inuit, whose maps "grow" and "develop," exemplifying the plasticity operative at their very heart. These maps do not suggest that the world is an empty container in which we move, and whose resources we exploit for our narrow purposes, but rather convey the sense that it is a world in the making, one where care, attention and responsibility are necessary to make homes among many other inhabitants within a thriving ecology that can exist only as a whole.

Malabou's commitment to the concept of plasticity also involves a reconsideration of writing in Plasticity at the Dusk of Writing (2010), where she postulates plasticity - "continuous implosion of form" - as the motor-scheme that supersedes the linguistic-graphic one (57-59). In this work, she traces the transformation of writing through the release of an artistic energy that (in Lyotard's words) "crumples and creases the text and makes a work from it"; this deconstructive energy would be in fact facilitated by plasticity, which in this account becomes the actual form of writing (56). This simultaneously calls for a plastic mode of reading, which "is a matter of causing the form that comes after presence to arise in works" (57; emphasis preserved). This form could be also understood as a certain kind of map left as 
an imprint that heralds the difference between the original experience and its record, the spacing discussed above. One caveat she adds, however, is that this imprint is not graphic but geo-graphic because it involves "assemblies, forms, or neuronal populations" (60; emphasis removed). Therefore, the post-deconstructive lesson that literary studies may draw from this is that purely textual, or mechanically deconstructive readings must yield before a more comprehensive, ecocentric approach that takes into account the neuronal, plastic underpinnings of the text. In this perspective, then, any text undergoes a material or geographic "worlding" through the way in which the environment sculpts the brain and in turn enables a fundamentally poetic "self-sculpturing," as Hugh J. Silverman puts it. This, he goes on to conclude, is where the significance of Malabou's "altermondialisation" rests:

\footnotetext{
Thus to speak with Malabou of an altermondialisation or "other-worlding" is to speak of the multiplicity of individual human bodies-brains and its/their ongoing process of self-fashioning as a sort of self-othering, self-re-forming, one through which the myriad of inter-connections ("synapses") within us becomes increasingly indistinguishable from the interconnected world/society/polis/culture outside of us and in which we live (Silverman 2010, 99).
}

To observe the process of "other-worlding," which finally collapses the distinction between map and territory, it might be fruitful to give voice to poetry by turning to a case study of a sequence of poems by the York-based poet Nigel Forde, whose works provide an opportunity to observe the concept of plastic cartography in practice.

\section{Nigel Forde's A Map of the Territory}

As we learn from the blurb, the 2003 volume by Nigel Forde "reflects [his] fascination with the process of change": his poems "meditate on memory and landscape," ultimately mapping "both a landscape and the mind that it has shaped." In this way, Forde's poems - especially the eponymous cycle that constitutes the heart of the book - offer a glimpse into the poetic becoming of a mind attuned to the landscape and environment that have imprinted themselves on the brain, forming a lyrical assemblage. "Remembered landscapes," Philip McCardle observes in a review of the collection, "are evoked as transitory, yet permanently ingrained upon the mind, with the empirical and reflective self colouring and giving substance to the moment" (2004). In this way, we are immediately drawn to the very process of 
mapping as recording and remembering, with the map being constituted by the brain (as suggested by the book's cover) - a brain that eventually comes to be the brain-world in the sense given to this term by Malabou. In an effort to "put his country boyhood together again" (as Peter Scupham put it in his endorsement), Forde is revisiting the environment that has shaped who he is, but in the course of his poetic reconstructions it becomes apparent that this landscape and his selves (past and present) have become enmeshed and impossible to divide. In this sense, writing poetry would be a mode of mental mapping insofar as poems chart the world's imprint and the temporal distance separating the formation of the brain from the lyrical enunciation.

The theme of writing-as-cartography has been extensively explored by Peter Turchi, who argues that each and every one of us is involved in "compiling mental atlases" whose vastness precludes communicating them fully; ultimately, he concludes, "we live in the world those maps create" $(2004,139)$. Poetry - or literature in general - could be regarded as a mode in which those things that are "too large to see" can be metaphorically brought forth (151) by employing specific devices, e.g. forms that act as a cartographic "geometric projection" that "evokes a world" (195). Forde does that by employing regular tercets throughout the sequence, constructing his own set of mapping parameters, and providing a rigid framework that organizes the poetic material in a way that longitude and latitude do.

Painstakingly registering fleeting details and emotions, Forde's attention is drawn to those things that the "Ordnance Survey doesn't know": "the other side of somewhere" or the ecological backdrop whose "taken-for-granted / Plainness is another kind of gift that haunts me" (24). The recurring theme of embeddedness in something much larger conveys the ecopoetic sense of being of the environment, not in it. As the lyrical subject notes, "I empty myself // Into the night's footsteps" (27) - an oft-repeated gesture that continuously blurs the boundary between the human subject and the world. "We sing the weave of language and of stone" (31), Forde says, embracing the materiality of poetry and foregrounding its home-making dimension. In the woods, he continues, we "stand [...] beyond metaphor, within it" (32, emphasis added). This place, "a cool // Forge of meanings and engagements" is the spring of signification; for all meaning is facilitated by one's entanglement in the environment, as a result of which "memory has landfall in these trees" (32) as landscape ultimately collapses into its poetic map.

In another turn of metaphor, Forde observes that "we bring home / More than the brittle jigsaws our boots drop / On the doormat"; indeed, we carry much more than mud on our soles: "The pattern // Of all that will not be patterned; the knowledge / Of something always at our shoulder; the memory / Of cold sky [...] a mirror of clouds" (33). That pattern revealed here can be interpreted as a metaphorical coming-to-light of the primary poetic and cartographic processes described by Malabou as the brains' plastic 
becoming-world. Meditating on the numerous past "selves" that haunt him through the landscape, Forde opens himself up in a gesture of fundamental vulnerability facilitated by the lyrical mode: "the sauntering home [...] melts into me and is gone." All boundaries dissolve as a "hedge switchbacks through my chest, three cows / Orbit my head, holly, painlessly, slaps my face" (36). Noticing that something is "sifting me," the lyrical subject ponders on the map-territory division, finally rejecting the dichotomy altogether:

$[\ldots]$ The real

Out there or the real in here? I can sit for ever

Between the two, imagining the truth of either,

Imagining, even, that I need to choose.

There is in fact no choice but to live the map - i.e. the brain - that is shaped both by the environment and by itself. Human activity is a continuous mapping and remapping of our engagements with the world, which in turn imprint themselves and change us. In the ecopoetic perspective, this process is not one of natural or cultural being but rather a non-dualistic joint becoming whose goal is homemaking. As Forde's sequence draws to a close, he paints a fragile picture of home, which is regarded as "what we make of what light leaves behind / Our eyes, our doors" (37) - a provisional room, a stanza, a poem to warm oneself by, suggesting both the larger world out there, unfathomable and inexhaustible, and the sense of being constituted by it insofar as it is always a particular place or region that ingrains itself materially in our selves, which is not unique to humans but also happens to other, non-human living beings: 
We light our lamps, illumine our small,

Shabby histories while starlings soak

Into the hedge with a noise that says how much

There is of everything and how it matters.

This passage displays all hallmarks of ecopoetics, as defined by Julia Fiedorczuk and Gerardo Beltrán, who consider it "a practice of homemaking, a way of engaging with other beings [...] with a heightened awareness of material and cosmic dimensions of our being [...] a practice of conscious becoming" (2015, 273). Through better poetic maps, Forde suggests, we can become more conscious of our past and future becomings - which is necessary in order to account for the plasticity that operates at the very heart of human subjectivity and learn to embrace it.

Importantly, Forde's maps are not merely a matter of rescuing a private history and remedying the loss of a world slipping away. This is not a sentimental exercise in the confessional mode, which redeems a pastoral landscape. As Forde argues in the sequence Touchstones from the same collection, utilizing the form of a crown of sonnets, we live in a world that has to be responsibly composed. Without heightened attunement to such practices, "[w]e slip through our own fingers / Without a tale for all that is elsewhere" (52). In this perspective, poetry can acknowledge both the brain that shapes its own accidents, and the world that speaks through it - a world "brooding imperatives / That adumbrate the present tense accounts / Our lives are written in" (55). Poems can never "outflank" reality, but instead produce a "fictive truth we call reality" that allows readers to recognize the "rhyme of unreason locked in every word" (57). Failing to acknowledge this, Forde concludes, effectually empties the world due to loss of wonder, making us stumble in the dark, and foreclosing the future, which can be easily "left behind," leaving us locked in the past invoked only to "prove the temper of the mind" (58). In the end, embracing the fragility of past selfhoods brings to focus the necessity to "dream and grow" when "through the dark our footsore futures go" (60).

In light of the foregoing, it needs to be ascertained that poetry can serve a dual role. On the one hand, it can be regarded as an aesthetic principle that operates on 
the metaphysical level (as it does in object-oriented philosophy, cf. Harman 2007), acquiring a more universal sense. On the other, however, it needs to be seen as a loose and diversified ensemble of idiosyncratic cultural practices that vary, often wildly, from one place to another, insofar as they express humanity's diverse relations with place and landscape. In the latter view, poetry does not merely "defamiliarize" reality to produce a certain aesthetic effect, but by engaging in estrangement suggests a wider world: greater expanses that escape our mapping and meaning-making efforts, in turn demanding a compositionist mindset to safeguard future becomings. This is closely related to a fundamental openness that allows poetry to embrace the kind of fragility and negativity that inform plasticity's formative and destructive character. Because plasticity is "as capable of destruction as of hope" means according to Jairus Grove - that "the collapse of nature and culture is a beginning, not a sufficient ending" (255). It is a call to face up to negativity, which can be ultimately located within plasticity itself.

Thus, Malabou's concept of plasticity allows new materialism to embrace some form of negativity. The failure to account for any operation of negativity has been one of the main accusations levelled against this movement by the likes of Adrian Johnston or Slavoj Žižek. Malabou's destructive plasticity does not offer simple consolation but foregrounds plasticity's potential horror (i.e. its potential to transform subjectivity into something that it cannot itself recognize), conveying the fragility of both human brain and its ecological condition of existence. Moreover, her diagnosis regarding numbness as one of today's key problems is pertinent and can be fruitfully aligned with the "wonder-inducing" practices of poetry. The restitution of wonder, which Malabou sees as the ground for feeling oneself at all (2013, 9), can be achieved in poetry, saving this crucial "affect of the other" from being permanently impaired (10) and allowing us to lay "the foundation for care" (51).

In the present perspective, Malabou's plasticity emerges as a link that can act as a materialism-based balancing point for three major discourses discussed here: schizoanalysis (with its focus on production of subjectivities), ecopoetics (with its emphasis on homemaking as poiesis), and new materialism (with its focus on entanglement and material interdependency, leading to a reconsideration of agency and causation). Through plasticity, we can think ecology as a materialist practice of meta-modelling our mental maps through poetic experimentation. This approach facilitates a more holistic and ecocentric view that posits a cartographic "absolute" - a totality of reality irreducible in any anthropocentric fashion, which nevertheless has to be imagined through metaphor in order to grasp the deep entanglement of humanity in its environment. This, in turn, can release the power to imagine better futures.

Praising poems by Garrett Hongo in the context of Catherine Malabou's notion of plasticity, David Palumbo-Liu argues that they "outline the dangerous borderland between 
the loss of memories, histories, values, and their regeneration and perpetuation through acts of learned and perceptive »brains«" (2012); this seems equally true for Forde and other similar projects of poetic mapping. As Catherine Malabou argues, the time of the Anthropocene is one of intense and precarious becomings, making it crucial to rise to the ambiguous challenge of plasticity and learn more about how we imprint ourselves on the world, and how it in turn shapes our brains. This can be achieved, as both Malabou and ecopoetics argue, by acknowledging the operation of a cartographic plasticity that makes us who we are by turning our brains into sites where metaphors forge connections between all manners of things out there in the world, assembling mappings that define the limits of our concern and care. At the same time, the fictive and poetic character of these maps leaves room for refining and updating them. Speculative and plastic mapping is something we can learn about from poetry, making it perhaps one of those forms of expression that could aid us in transforming our home-making practices into ones that would be more responsible and empathic. 


\section{Wykaz literatury}

Bishop, Elizabeth. 2011. Poems. Edited by Saskia Hamilton. New York: Farrar, Straus and Giroux.

Bristow, Tom. 2015. The Anthropocene Lyric: An Affective Geography of Poetry, Person, Place. New York: Palgrave Macmillan.

Citton, Yves. 2016. "Fictional Attachments and Literary Weavings in the Anthropocene." New Literary History 47: 309-329.

Fallon, Ann Marie. 2016. Global Crusoe: Comparative Literature, Postcolonial Theory and Transnational Aesthetics. London: Routledge.

Fiedorczuk, Julia \& Gerardo Beltrán. 2015. Ekopoetyka/Ecopoética/Ecopoetics. Warsaw: Biblioteka Iberyjska.

Ford, Katie. 2007. "Visibility Is Poor: Elizabeth Bishop's Obsessive Imagery and Mystical Unsaying." Poets.org. April 13, 2007. https://www.poets.org/poetsorg/text/visibilitypoor-elizabeth-bishops-obsessive-imagery-and-mystical-unsaying.

Forde, Nigel. 2003. A Map of the Territory. Manchester: Carcanet.

Guattari, Félix. 2000. The Three Ecologies. Translated by Ian Pindar and Paul Sutton. London: Athlone Press.

Guattari, Félix. 2013. Schizoanalytic Cartographies. Translated by Andrew Goffey. London: Bloomsbury.

Grove, Jairus. 2015. "Something Darkly This Way Comes: The Horror of Plasticity in an Age of Control." In Plastic Materialities. Politics, Legality, and Metamorphosis in the Work of Catherine Malabou, edited by Brenna Bhandar \& Jonathan Goldberg-Hiller, 233-263. Durham: Duke University Press.

Harman, Graham. 2007. “On Vicarious Causation.” Collapse II: 171-206.

Ingold, Tim. 2000. The Perception of the Environment. Essays on Livelihood, Dwelling and Skill. London: Routledge.

King, Geoff. 1996. Mapping Reality. An Exploration of Cultural Cartographies. New York: Palgrave Macmillan.

Malabou, Catherine. 2008. What Should We Do with Our Brain? Translated by Sebastian Rand. New York: Fordham University Press.

Malabou, Catherine. 2010. Plasticity at the Dusk of Writing. Translated by Carolyn Shread. New York: Columbia University Press.

Malabou, Catherine. 2012. Ontology of the Accident. An Essay on Destructive Plasticity. Translated by Carolyn Shread. Cambridge: Polity Press.

Malabou, Catherine \& Adrian Johnston. 2013. Self and Emotional Life. Philosophy, Psychoanalysis, and Neuroscience. New York: Columbia University Press.

Malabou, Catherine. 2016. "What is Neuro-Literature?" SubStance 45.2: 78-87.

Malabou, Catherine. 2017. "The Brain of History, or, The Mentality of the Anthropocene." The South Atlantic Quarterly 116.1: 39-53.

McCardle, Philip. 2004. "Sacred Music." Review of A Map of the Territory, by Nigel Forde. PN Review 31.1. http://www.pnreview.co.uk/cgi-bin/scribe?item_id=2171.

Palumbo-Liu, David. 2012. "Poetry, Politics, Plasticity, Re-imagination." Arcade: Literature, the Humanities, \& the World, April 20, 2012. http:/ / arcade.stanford.edu/blogs/poetrypolitics-plasticity-re-imagination.

Pickard, Zachariah. 2004. "Natural History and Epiphany: Elizabeth Bishop's Darwin Letter."

Twentieth Century Literature 50.3: 268-282. 
Reinertsen, Anne B. 2016. Becoming Earth. A Post Human Turn in Educational Discourse Collapsing Nature/Culture Divides. Rotterdam: Sense Publishers.

Silverman, Hugh J. 2010. "Malabou, Plasticity, and the Sculpturing of the Self." Concentric: Literary and Cultural Studies 36.2: 89-102.

Turchi, Peter. 2004. Maps of the Imagination: The Writer as Cartographer. San Antonio: Trinity University Press.

Vahanian, Noëlle. 2008. "A Conversation with Catherine Malabou.” The Journal for Cultural and Religious Theory 9.1: 1-13. 
Grzegorz Czemiel - Ph.D., is Assistant Professor in the Department of Anglo-Irish Literature at the Maria Curie-Skłodowska University in Lublin. His academic interests include contemporary poetry, translation studies as well as new literary theory and philosophy, especially ecopoetics and Speculative Realism. Currently, he is developing the concept of "speculative cartography," involving poetry as a geophilosophical mode of making cognitive maps and facilitating an ecological engagement with the world. He also translates poetry, criticism and academic texts.

\section{ADDRESS:}

Zakład Literatury Angloirlandzkiej,

UMCS,

Plac Marii Curie-Skłodowskiej 4A, 20-031 Lublin

EMAIL: grzegorz.czemiel@poczta.umcs.lublin.pl

CITATION: Czemiel, Grzegorz. 2018. „Plastic Cartographies. Map and territory in Catherine Malabou and Ecopoetics.“ Praktyka Teoretyczna 2(28): 30-50.

DOI: $10.14746 /$ prt.2018.2.2

\section{AUTOR: Grzegorz Czemiel}

TYTUL: Plastyczne kartografie. Mapa i terytorium w perspektywie ekopoetyki i filozofii Catherine Malabou

ABSTRAKT: Artykuł poświęcony jest figurze mapy i terytorium w filozofii Catherine Malabou i współczesnej poezji. Problematyzując tradycyjne rozumienie napięcia między mapa a terytorium, Malabou podkreśla fakt, że żadna mapa nie może oderwać się od terytorium, co potwierdza jej analiza tego, jak mózg rozwija się w kontakcie ze środowiskiem. Malabou używa koncepcji kartograficznych opracowując pojęcia "plastyczności" oraz "kartografii świata-mózgu," które pozwalają ująć to, jak kształtowani jesteśmy przez środowisko, wskazując tym samym sposoby, w jakie możemy wpływać na ten proces. Zastosowanie tej perspektywy do analizy wybranych utworów Elizabeth Bishop i Nigela Forde'a pozwala ukazać zbieżność poetyk tych autorów z podejściem Malabou i programem teoretycznym ekopoetyki, dając zarazem podstawę do wysunięcia tezy, że poezja dostarcza narzędzi koniecznych do tworzenia lepszych, zrównoważonych "ekologii umysłu". To zadanie wysuwa się na pierwszy plan w kontekście kryzysu ekologicznego i etycznych wyzwań, jakie niosą ze sobą nastanie epoki antropocenu i rozwój zderegulowanego globalnego kapitalizmu.

SŁOWA KLUCZOWE: plastyczność, kartografia, mapowanie, poezja, ekopoetyka. 